\title{
BETTER NUTRITION FOR A HEALTHIER WORKFORCE
}

\section{A SUMMARY REPORT OF A WORKSHOP}



GAIN Convening Paper Series $n^{\circ} 1$

July, 2019

The Global Alliance for Improved Nutrition and The Consumer Goods Forum



\section{ABOUT GAIN}

The Global Alliance for Improved Nutrition (GAIN) is a Swiss-based foundation launched at the UN in 2002 to tackle the human suffering caused by malnutrition. Working with governments, businesses and civil society, we aim to transform food systems so that they deliver more nutritious food for all people, especially the most vulnerable.

\section{ABOUT THE CONSUMER GOODS FORUM}

The Consumer Goods Forum ("CGF") is a global, parity-based industry network that is driven by its members to encourage the global adoption of practices and standards that serves the consumer goods industry worldwide. It brings together the CEOs and senior management of some 400 retailers, manufacturers, service providers, and other stakeholders across 70 countries. Its member companies have combined sales of EUR 3.5 trillion and directly employ nearly 10 million people, with a further 90 million related jobs estimated along the value chain.

\section{Recommended citation}

The Global Alliance for Improved Nutrition (GAIN) and The Consumer Goods Forum (CGF), 2019. Better Nutrition for a Healthier Workforce: A Summary Report of a Workshop. Global Alliance for Improved Nutrition (GAIN). Convening Paper Series \#1. Geneva, Switzerland, 2019. DOI:

https://doi.org/10.36072/cp.1

\section{(C) The Global Alliance for Improved Nutrition (GAIN)}

The contribution of third parties do not necessarily represent the view or opinion of GAIN.

This work is available under the Creative Commons Attribution-Non-Commercial-Share Alike 4.0 IGO licence (CC BY-NC-SA 4.0 IGO; https://creativecommons.org/licenses/by-nc-sa/4.0/). Under the terms of this licence, you may copy, redistribute and adapt the work for non-commercial purposes, provided the work is appropriately cited, as indicated below. In any use of this work, there should be no suggestion that GAIN endorses any specific organisation, products or services. The use of the GAIN logo is not permitted. If you adapt the work, then you must license your work under the same or equivalent Creative Commons license.

\section{Acknowledgements}

GAIN and CGF would like to thank Genevieve Stone and Christina Nyhus Dhillon for developing this paper and to the additional organisers of the programme, including Pauline Harper, Bärbel Weiligmann, Mirjam van der ZijdenKneepkens, Andoni Santamaria Kampfner, Eva Kritharelli, Joelle Mbuya Leclerc, and Sharon Bligh. We gratefully acknowledge the financial support of the Dutch Ministry of Foreign Affairs for this workshop, as well as the Making Markets Work Programme supported by the Dutch Ministry of Foreign Affairs, Germany's Federal Ministry of Economic Cooperation and Development, Irish Aid, Swiss Development Cooperation, Canada's International Development and Research Center, and the Bill and Melinda Gates Foundation.

\section{GAIN CONVENING PAPER series}

The GAIN Convening Paper Series brings together proceedings and reports from events that have been convened or co-convened by GAIN.

The Global Alliance for Improved Nutrition (GAIN)

Rue de Varembé 7

1002 Geneva

Switzerland

T: +41227491850

E: info@gainhealth.org

www.gainhealth.org 


\section{SUMMARY}

Employers can play an important role in reducing the global burden of malnutrition and empowering employees to live healthier lives. Workers spend most of their waking hours in a working context- whether in an office, a factory, or a farm-and that context can be either an enabler or a barrier to positive nutrition and health behaviours. Workforce Nutrition (WFN) Programmes are a broad set of actions that employers can take to improve the nutrition and health of their workers. They are implemented through the existing structures of the workplace. WFN programmes can address a wide variety of nutrition-related problems, from underweight to obesity, iron-deficiency anaemia to diabetes.

A meeting was convened by The Global Alliance for Improved Nutrition (GAIN) and The Consumer Goods Forum (CGF) on July $3^{\text {rd }}$ and $4^{\text {th }}, 2019$ in Geneva, Switzerland. The aim of the meeting was to achieve consensus on the why, what and how of improving employee nutrition, by addressing the main challenges around workforce nutrition, sharing best practices and learnings regarding implementation of programmes in the workplace, and looking to the future to seek shared opportunities. The meeting was attended by a broad range of stakeholders who are actively involved in WFN programmes.

This paper reports on the discussions and outcomes of this Better Nutrition for a Healthier Workforce workshop. The main outcome was the creation of a strategic alliance, to be led by GAIN and the CGF, to put WFN on the global agenda, including at the Tokyo 2020 Nutrition for Growth summit. Several individuals present at the meeting made public commitments towards WFN, either on behalf of their organisation or as individuals.

\section{KEY MESSAGES}

- Employers and workplaces can be leveraged to address the nutritional health of workers across all sectors, from corporate offices to supply chains.

- The evidence behind workforce nutrition interventions suggests a clear win-win for both employees and employers.

- Workforce nutrition can be integrated into existing health and wellness programmes for employees, or resilience or livelihood programmes for smallholder farmers, and become part of core business activities.

- Commitments are needed from employers and businesses to further scale up workforce nutrition interventions.

- A newly formed alliance will work to position these actions on the agenda for the Tokyo 2020 Nutrition for Growth summit and beyond. 


\section{BACKGROUND AND OBJECTIVE}

One in three people globally is malnourished, making it likely that most employers face challenges related to employee malnutrition, including significant losses in productivity and potential (1). Given that most adults globally will spend at least one third of their time at work, occupational health is a key determinant of overall wellbeing (2). Globally, approximately 2 out of 3 companies with effective health and productivity programmes believe they perform better than their competitors. WFN programmes respond to both employee and employer needs, presenting a significant opportunity for the public and private sectors to collaborate to reduce the global malnutrition burden and drive business value.

Workforce nutrition (WFN) programmes include a broad set of actions that employers can take to improve the nutrition and health of their workers. The notion of the 'workforce' encompasses the full spectrum of workers, including direct employees in factories, headquarter offices, and other settings as well as indirect workers, such as smallholder farmers in supply chains. WFN programmes are implemented through the existing delivery structures of the 'workplace', can be integrated into company policy, and can play a role in addressing a wide variety of nutritionrelated problems, from underweight to obesity, iron-deficiency anaemia to diabetes. For example, interventions can include providing healthy and affordable food at work or promoting good nutrition practices through employee education programmes. A combination of many approaches would likely have the greatest impact. Such initiatives could be integrated into existing health and wellness programmes, or other employee welfare programmes.

Employers have a unique opportunity to impact the health and wellbeing of their employees. Indeed, there has been growing demand for information about how to design and deliver effective programmes that improve nutrition in the workplace, for the benefit of both employees and businesses. This demand is coming from multiple and varied sources. For example, the SUN Business Network recently incorporated workforce nutrition commitments into membership engagement principles, and the International Labour Organization's (ILO) Better Work programme recognises that healthy food provision is demanded by workers and is part of the Decent Work agenda of SGD8. In addition, initiatives such as the CGF's Collaboration for Healthier Lives (CHL) have emerged with the aim respond to such demands by encouraging businesses to empower their employees to make healthier choices and live healthier lives. Moreover, several food industry companies face increasing consumer pressure to address hunger and health issues across supply chains.

\section{OVERVIEW OF THE MEETING}

Recognising these trends, the Global Alliance for Improved Nutrition (GAIN) and The Consumer Goods Forum (CGF) co-hosted a technical workshop to bring together partners from the public and private sectors to discuss best practices and identify opportunities to build momentum on WFN ahead of the Global Nutrition Summit in Tokyo 2020'.

\footnotetext{
1 The Global Nutrition Summit will be hosted by the Government of Japan and in conjunction with the Olympic and Paralympic games and aims to secure new and refreshed policy and financial
} 
The workshop set out to meet the following objectives:

1. Share experiences amongst partners on WFN efforts;

2. Take stock of current approaches to WFN and the available evidence on what works;

3. Identify the elements of WFN programmes that seem most promising; and

4. Encourage and guide businesses to make more effective commitments on WFN programmes.

The attendees of the workshop included a range of partners: donors, government representatives, health and wellness experts in multinational companies, factory managers, research specialists, private-sector coalitions, NGOs providing technical assistance for WFN programmes, and UN organisations. Geographically, representatives came from Africa, Asia, Europe, North America, and Oceania. See Annex 1 for the meeting agenda with participating organisations.

The following sections will outline key elements of the discussion that emerged over the course of the workshop to address the why, what and how of workforce nutrition.

BOX 1. DEFINING A WORKFORCE NUTRITION PROGRAMME (SOURCE: STONE \& NYHUS DHILLON, 2019)

Workforce nutrition programmes are a set of interventions that operate through the existing delivery structures of the workplace to address fundamental aspects of nutrition amongst employees or supply chain workers. Ideally, these programmes aim to improve diets, physical activity levels and ultimately worker's health, resilience and wellbeing. Breastfeeding support programmes are included in this definition, as they enable working parents to provide adequate nutrition to their infants and support maternal health.

\section{WHY WORKFORCE NUTRITION PROGRAMMES ARE IMPORTANT}

The current global nutrition burden is large, with 2 billion people overweight or obese, 2 billion people suffering from micronutrient deficiencies, and 800 million people undernourished (3). There is an urgent need to find innovative and scalable solutions, and both the public and private sectors can play a role in this. WFN programmes, in their ability to reach a vast portion of the population in their daily work environment, offer an important opportunity for the private sector to contribute to reducing the burden of malnutrition and poor health. Perhaps equally important, the attention to the wellbeing of workers through the provision of food lifts the dignity of workers and contributes to the decent work agenda, in low-wage sectors. Despite these compelling grounds for action, workforce nutrition is not currently prominent on the global nutrition agenda.

commitments from governments, civil society, private sector, donor agencies and the UN to act on reducing malnutrition in all its forms by 2030 as part of the Sustainable Development Goals. 
The workshop used this motivation as a starting point, demonstrating that there is considerable empirical evidence of the benefits of workforce nutrition programmes to both individuals and businesses, though more needs to be known about best practices for designing and implementing them. A summary of a recent literature review by GAIN was presented, highlighting the benefits to both employees and employers. These include reductions in anaemia, overweight/obesity, and diet-related non-communicable diseases as well as increased job satisfaction and lower rates of absenteeism (missed work days due to illness) and presenteeism (employees being present at work but with lowered productivity)(4-8). Identified gaps and challenges in evidence generation included: a lack of access to evidence from many currently ongoing programmes, difficulties in attributing business outcomes to nutrition improvements in multifaceted workplace settings, and a lack of evidence on the impact of WFN programmes on undernutrition in low-resource settings.

A presentation by NewForesight on the 'business case' for addressing nutrition led to a lively discussion. Three case studies presented the motivations of different value chain actors in the garment, tea, and cocoa sectors for investing in the nutritional health of workers. The motivations varied by sector and actor but included: increased revenues, decreased costs, securing (quality) supplies, attracting customers, attracting and retaining talent, mitigating reputational risk or improving brand reputation, fulfilling sustainability commitments, strengthening a sustainability approach, and responding to an external need or request. The business case resonated with many private-sector participants in the workshop, who agreed that the 'bottom line', or what is traditionally considered the business case, was rarely the motivation to initiate a WFN programme. Throughout the workshop, other motivating factors emerged, including improving community resilience, increasing employee loyalty and satisfaction, and improving employer-employee relationships. Although varied motivations often instigate programmes, the bottom line is often important for sustaining them.

Gender was also highlighted as a key aspect to consider within WFN programmes, as female workers are often more nutritionally vulnerable than male workers due to specific needs during reproductive years, a larger burden of care work within the home, and unequal access to food in many parts of the world. Attention to gender is especially important in the specific sectors where labour is female-dominated, as is the case with tea production and garment manufacturing.

\section{WHAT DO WORKFORCE NUTRITION PROGRAMMES LOOK LIKE?}

The review of the literature presented by GAIN also indicated four thematic areas where effectiveness has been shown. These were as follows: 1) provision of healthy food at work, 2) nutrition education, 3) nutrition-focused health checks, and 4) workplace breastfeeding support (9). It was suggested that these could be used as a framework for further characterising workforce nutrition, as presented in Figure 1 (Annex 2). Workshop participants widely supported these intervention groupings, adding a few additional comments. Specifically, it was felt that for supply chain workers, programmes are not as siloed and tend to be embedded into broader resilience and livelihood programmes. Also, for some companies, promotion of physical activity was considered a component of nutrition programmes. 
Although WFN programme areas can be broadly categorised into these four intervention approaches, their operationalization varies greatly. This was clear as workshop participants shared their models. In more official workplaces, like corporate office and factory settings, programme examples included:

- Promotion of the Mediterranean diet amongst employees to address nutrition and planetary health. This programme was developed in collaboration with a university and involved a nutrition education component, which was delivered through an app that enabled tracking employee's food consumption to calculate health and sustainability impact, as well as an access component, which involved improving canteen menus.

- Promotion of physical activity amongst employees in corporate offices with gym memberships or other incentives, alongside nutritional health education.

- In a garment factory, nutrition education through peer educators and the improvement of canteen meals, including offering iron-fortified rice.

In more informal work contexts among supply chain workers, different channels were used, including the following:

- A programme in Kenya uses social media and radio to communicate nutrition messages to tea farmers, as these were identified as popular forms of entertainment and had wide reach. The programme also engages kiosk sellers in tea farming areas to share information about fortified products and healthy food choices with farmers.

- A programme in Ghana works with Farmer Field Schools-a group-based agricultural training approach—to deliver nutrition messages to cocoa farmers. To improve access to nutritious foods, this programme promotes crop diversification with nutrient-dense foods (e.g. vegetables) amongst farmers as part of broader resilience efforts intended to positively influence nutrition.

Whilst a few businesses had started such programmes almost a decade ago, many of those gathered in the convening were actively adapting programs and identifying best practices and therefore welcomed the opportunity to share learnings and experiences.

\section{HOW TO IMPLEMENT WORKFORCE NUTRITION FOR SUSTAINED IMPACT}

With compelling motivation, convincing evidence, and some good examples of programme models, the focus of much of the workshop was on the how: how best to implement these programmes to achieve both impact and sustained integration into business models.

Through roundtable discussions, a variety of tools to support the design and implementation of WFN programmes were presented. The tools discussed included methodologies for assessing the business case and for estimating the costs of a healthy diet and how-to guides on lactation support in the workplace and on the provision of healthy foods at work. Other attendees presented national guidelines to support healthy food in workplace canteens, an accountability tool to asses workplace actions, and a mechanism to assess service delivery models for supply chain workers, within which nutrition services could be integrated. Links to these tools and their intended audience are outlined in more detail in Table 1 (Annex 3). Participants felt that additional tools would be useful, including costing tools, business- and 
user-friendly monitoring tools, and a mapping of all existing WFN interventions to enhance cross-learning and avoid duplication of efforts.

Business representatives in the meeting also felt that communicating scientific findings to a business audience was also needed. This discussion was particularly relevant after representatives from the Institute of Grocery Distribution (IGD) shared ongoing research findings on effective ways promote healthy eating behaviours through workplace cafeterias in the United Kingdom. Useful learning, for example, demonstrated that offering healthier food options and decreasing portion sizes were more effective than calorie labelling. This work offered a good example of how coordinated efforts on a large scale can generate practical programme insights and also successfully convert those learning into an accessible resource for businesses.

Other key constraints and challenges in implementing and scaling up WFN programmes were identified and discussed within smaller working groups. Specifically, participants discussed effective communication of learnings, the need (or lack thereof) for more evidence, the challenge of expanding programmes across a company's full workforce, defining the role the public sector can play in supporting WFN programmes, and how to effectively reach supply chain workers. Table 2 (Annex 4) provides more details on some of the solutions proposed. The key challenges that dominated the discussions related to unlocking funding within businesses and the roles non-business partners can play in supporting employee-led efforts.

It was agreed that a fertile, level playing field is important for creating an enabling environment for WFN within any given sector at local, national, and international levels. Local legislation, such as maternity leave laws or food at work laws, can support WFN programmes but could be strengthened to be more nutrition specific. Public sector funding (as a blended finance approach) was identified as ideal for supporting the generation of evidence, technical assistance, coordination and acceleration of global action, and setting incentives for businesses-all of which would support direct investments by businesses. Finally, consumers and civil society groups can advocate for the private sector to adopt more ethical sourcing practices in supply chains where workers are particularly vulnerable.

Although current evidence was found to be convincing and robust, many still felt that specific evidence that enables building a business case is often needed to justify sustained investments or scale up within a company. Common and key metrics to track and map current efforts would be helpful for businesses to strengthen their own programmes through shared learnings. Although not widely practiced, regular programme monitoring was felt to be critical in all contexts. 


\section{DECISIONS, FUTURE PLANS AND ACTION ITEMS}

There was unanimous agreement amongst the workshop participants on the need and importance of WFN programmes. This was not surprising, as many invited participants represented frontrunners in this area. Participants felt the need for continued dialogue through a community of WFN champions. Such a network would allow members to strategize on a global scale about how better nutrition for employees could become a core part of business. Based on this recognition, a clear coalition of the willing (and able) emerged from this convening with a strong motivation to work together to advance global action for WFN.

It was acknowledged that different WFN efforts are operating within and across organizational silos, with little sharing of challenges and learnings. For example, one department may coordinate health programmes for direct employees (e.g., corporate office staff) but may not be liaising with the departments that coordinate resilience and wellbeing programmes for 'indirect' employees (e.g., supply chain workers). While the nutritional needs and work contexts may vary greatly between these worker sub-groups, it was felt that a lack of cross-learning was impeding WFN initiatives from achieving the momentum needed to drive large-scale and cross-sector global action. There was an expressed need to connect these programmes across the whole workforce spectrum within businesses.

To this end, the convening concluded with an agreement to form an alliance, co-led by GAIN and the CGF to coordinate, mobilise and accelerate scalable action in nutrition programmes across the full spectrum of the workforce. This alliance will:

\section{Share evidence and create a business case for action}

a. Structure the case for action alongside a matrix of areas of intervention, containing the latest evidence related to each

b. Gather metrics beyond economic and nutritional impact, including measures of dignity, happiness, and wellbeing

c. Improve the narrative around workforce nutrition, emphasise storytelling to bridge the gap between research, businesses, consumers, and citizens

\section{Advocate proactively}

a. Promote progressive leadership and share success stories, champion front-runner companies

b. Promote endorsement of WFN amongst business umbrella organisations; the CGF will internally cluster activities of its 400 members around different programmatic areas to encourage learning and facilitate action

\section{Support benchmarking standards}

a. Advocate to integrate WFN within existing accountability mechanisms, such as BCorp and the World Benchmarking Alliance

b. Expand Access to Nutrition Index indicators to include lifestyle programs that address not just employees but also supply chain workers

4. Connect better nutrition for employees to the value chain, inclusive of large and small-sized companies and organizations 
a. Promote the connection of Human Resources teams and Value Chain teams in relevant organizations to promote the scaling-up of programmes beyond corporate offices where relevant and possible

b. Strategize with Small- and Medium-Sized Enterprise umbrella organisations, such as the SUN Business Network, on how to meet their diverse needs and facilitate peer support

Future developments related to the alliance will be shared online through the Workforce Nutrition section of Nutrition Connect, as well as through the individual websites of GAIN and the CGF. The alliance will seek to integrate action with ongoing efforts towards the Tokyo 2020 Global Nutrition Summit and related commitments.

The potential for scaling-up action through the alliance is great: combining technical capacity from civil society partners, business expertise and reach from business membership platforms, and public-sector support from SUN and the International Labour Organization (ILO). CGF members alone have the potential to reach 10 million direct and 90 million indirect workers.

In addition, the enthusiasm generated from the gathering led to tangible organisational public commitments (as seen in Box 2, below) as well as 17 individual commitments from participants to become advocates for WFN within their organisations and beyond.

BOX 2. SUMMARY OF ORGANISATIONAL WORKFORCE NUTRITION COMMITMENTS

- Katja Freiwald, Director of Global Partnerships, Unilever: As Unilever, commits to invest money and resources for the next three years to act as a catalyst for workforce nutrition in the tea industry globally. 750,000 EUR will be invested in a pooled fund to incentivise other public- and private-sector actors to match the funding.

- Lawrence Haddad, Executive Director, GAIN: Commits to setting up an internal WFN programme for GAIN employees across all offices within one year.

- Sudi Biko Matara, Head of Foundation, Kenyan Tea Development Agency: Commits to doubling the allocations to the KTDA Foundation health pillar from 50,000 USD to 100,000 USD as of June 2020, of which a signification proportion will be designated for nutrition.

- Isabelle Grosmaître, Co-Chair of Health and Wellness Pillar, CGF, and Alimentation Catalyst, at Danone: Commits to collaborate with GAIN to join forces to learn from proactive companies and to bring the case forward towards Tokyo 2020.

- Pauline Harper, Director of Health and Wellness, CGF: 1) Help bring the business case together, 2) Identify and share best practices from CGF members, 3) Demonstrate internally developed tools in Tokyo. 


\section{REFERENCES}

1. HLPE. Nutrition and food systems. A report by the High Level Panel of Experts on Food Security and Nutrition of the Committee on World Food Security. RO: FAO; 2017 p. 152.

2. WHO. WHO Global Plan of Action on Worker's Health (2008-2017): Baseline for Implementation. Geneva; 2013.

3. Afshin A, Sur PJ, Fay KA, Cornaby L, Ferrara G, Salama JS, et al. Health effects of dietary risks in 195 countries, 1990-2017: a systematic analysis for the Global Burden of Disease Study 2017. The Lancet. 2019 May;393(10184):1958-72.

4. Berry LL, Mirabito AM, Baun WB. What's the hard return on employee wellness programs? Harv Bus Rev. 2010 Dec;88(12):104-12, 142.

5. Dinour LM, Szaro JM. Employer-based programs to support breastfeeding among working mothers: A systematic review. Breastfeed Med. 2017;12:131-41.

6. Weerasekara YK, Roberts SB, Kahn MA, LaVertu AE, Hoffman B, Das SK. Effectiveness of workplace weight management Interventions: a systematic review. Curr Obes Rep. 2016 Jun;5(2):298-306.

7. Wanjek C. Food at work: workplace solutions for malnutrition, obesity and chronic diseases. Geneva: ILO; 2005. 448 p.

8. Warner KE, Wickizer TM, Wolfe RA, Schildroth JE, Samuelson MH. Economic implications of workplace health promotion programs: review of the literature. J Occup Med. 1988 Feb;30(2):106-12.

9. Stone G, Nyhus Dhillon C. The evidence for workforce nutrition programmes. In: The Global Alliance for Improved Nutrition. Geneva, Switzerland; 2019. 


\section{ANNEX 1}

\section{Agenda, Better Nutrition for a Healthier Workforce}

JULY 3, 2019

\begin{tabular}{|c|c|c|c|}
\hline Time & Topic & Organisation & Speaker \\
\hline $9: 00$ & \multicolumn{3}{|l|}{ Welcome/Introductions } \\
\hline \multicolumn{4}{|c|}{ Session One: Perspectives on Workforce Nutrition } \\
\hline $9: 15-09: 30$ & Why invest in nutrition in the workplace? & $\begin{array}{l}\text { The Global Alliance for Improved } \\
\text { Nutrition (GAIN) }\end{array}$ & Lawrence Haddad, Executive Director \\
\hline $9: 30-9: 45$ & Private sector perspective & $\begin{array}{l}\text { Danone/ Health and Wellness Pillar, } \\
\text { The Consumer Goods Forum (CGF) }\end{array}$ & $\begin{array}{l}\text { Isabelle Grosmaître, Alimentation Catalyst, } \\
\text { Co-Chair Health \& Wellness CGF }\end{array}$ \\
\hline $9: 45-10: 00$ & Better Work program and evidence around food at work & $\begin{array}{l}\text { International Labour Organization / } \\
\text { Better Work }\end{array}$ & Dan Rees, Better Work Chief \\
\hline
\end{tabular}

Session Two: Defining Workforce Nutrition and Review of the Evidence

\begin{tabular}{|c|c|c|c|}
\hline \multirow{3}{*}{ 10:30-11:30 } & Review of the literature on workforce nutrition programmes & $\begin{array}{l}\text { The Global Alliance for Improved } \\
\text { Nutrition (GAIN) }\end{array}$ & Lynnette Neufeld, Director Knowledge Leadership \\
\hline & $\begin{array}{l}\text { Healthier eating in the workplace: Results from a large- } \\
\text { scale trial }\end{array}$ & $\begin{array}{l}\text { The Institute of Grocery Distribution } \\
\text { (IGD) }\end{array}$ & $\begin{array}{l}\text { Jon Woolven, Strategy and Innovation } \\
\text { Director }\end{array}$ \\
\hline & Business case for Workforce Nutrition & NewForesight & $\begin{array}{l}\text { William Saab, Strategic Advisor, Sustainable } \\
\text { Business Models }\end{array}$ \\
\hline
\end{tabular}


Session Three: Panel on Workforce Nutrition Private Sector Experiences

$11: 30-12: 30$

Panelists representing their experiences across a variety of settings and sectors

\begin{tabular}{|l|l|}
\hline BEL Group & $\begin{array}{l}\text { Cécile Biansan, Nutrition Manager for Africa and } \\
\text { Middle East }\end{array}$ \\
\hline Nestlé / FReSH Coalition & Karen Cooper, Sustainability Leader \\
\hline Touton & $\begin{array}{l}\text { Anaëlle Evano, Sustainable Sourcing, Business } \\
\text { \& Innovations Manager }\end{array}$ \\
\hline $\begin{array}{l}\text { Kenya Tea Development Agency } \\
\text { Foundation }\end{array}$ & \begin{tabular}{l} 
Sudi Matara, Head of Foundation \\
\hline Lenny Fashions Ltd.
\end{tabular} \\
\hline Barilla & $\begin{array}{l}\text { Menammad Murtaza Karim, } \\
\text { Genanager }\end{array}$ \\
\hline
\end{tabular}

\section{Session Four: Round Tables on Tools for Workplace Nutrition}

\begin{tabular}{|c|c|c|}
\hline Table 1 : Toolkit for the provision of healthy food at work & Eat Well Global & Erin Kappelhof, Managing Partner \\
\hline $\begin{array}{l}\text { Table } 2 \text { : Service Delivery Models for small holder farmers in } \\
\text { supply chains }\end{array}$ & Sustainable Trade Initiative (IDH) & $\begin{array}{l}\text { Gaël Lescornec, Program Manager Cocoa, Food Security \& } \\
\text { Gender }\end{array}$ \\
\hline Table 3: Business case modelling for investing in nutrition & NewForesight/ GAIN & William Saab, Strategic Advisor, Sustainable Business Models \\
\hline Table 4: Breastfeeding Support in the Workplace & Alive \& Thrive & Kristen Kappos, Associate Director for South Asia Programmes \\
\hline Table 5: Access to Nutrition Index: Self- Assessment Tool & Access to Nutrition Initiative & Efimia Chatzinikolau, Programme Manager \\
\hline Table 6: Guidelines for Healthy Canteens in Sri Lanka & Ministry of Health, Sri Lanka & Bhanuja Wijayatilaka, Consultant Community Physician \\
\hline Table 7: Living income/wage's costs of a healthy diet & Global Living Wage Coalition & Martha Anker, Independent Researcher \\
\hline
\end{tabular}


Session Five: Working Groups

Group 1: How much and what kind of evidence do we still need on what works?

Group 2: How do we move from corporate offices in high income countries to non-corporate, factory or farming settings in developing countries with WPN programmes?

Group 3: How should we assess the effectiveness of

workplace nutrition programmes? What are the business, nutrition and/or diet metrics? What are the evaluation

designs that make sense in company settings?

Group 4: How do we reach smallholders for better nutrition - crop diversification is not the golden bullet

Group 5: How can we develop smart funding mechanisms? Who needs support and who does not?

Group 6: How do we communicate our successes and learn amongst ourselves?

Led by Bhanuja Wijayatilaka (Consultant Community Physician, Ministry of Health, Sri Lanka) and Helen Wray (Health \& Wellbeing Lead Europe \& Russia, Mars) - supported by Geneviève Stone

Led by Stefano Severi (Ferrero) and Jazz Smith-Kaira (VF Corporation)- supported by Laurène Aubert

Reporting back on key agreements lead by working groups

Closing of the Day- Reflections and Recap
The Global Alliance for Improved

Nutrition (GAIN)
Lawrence Haddad, Executive Director 


\section{Agenda, JULY 4, 2019}

\begin{tabular}{|c|c|c|c|c|}
\hline Time & & Topic & Organisation & Speaker \\
\hline \multicolumn{5}{|c|}{$\begin{array}{l}\text { 8:30 Welcome and Introductions: Lawrence Haddad, Executive Director of The Global Alliance for Improved Nutrition and Isabelle Grosmaître, Alimentation Catalyst DANONE } \\
\text { Co Chair Health \& Wellness CGF }\end{array}$} \\
\hline $8: 45$ & Opening & $\begin{array}{l}\text { Why invest in the wellness of farmers and } \\
\text { workers in LMICs }\end{array}$ & $\begin{array}{l}\text { Patron of Save the } \\
\text { Children/Dutch Princess }\end{array}$ & $\begin{array}{l}\text { HRH Princess Viktória de Bourbon de } \\
\text { Parme, Patron }\end{array}$ \\
\hline \multirow{5}{*}{$\begin{array}{l}9: 00- \\
10: 00\end{array}$} & \multirow{5}{*}{$\begin{array}{l}\text { Public Sector Actions for } \\
\text { Workforce Nutrition: Moving } \\
\text { Forward }\end{array}$} & $\begin{array}{l}\text { Current state of Workforce Nutrition } \\
\text { programmes and looking to the future }\end{array}$ & $\begin{array}{l}\text { The Global Alliance for } \\
\text { Improved Nutrition (GAIN) }\end{array}$ & $\begin{array}{l}\text { Lawrence Haddad, Executive Director } \\
\text { (Moderator) }\end{array}$ \\
\hline & & UNICEF Mothers@Work Programme & UNICEF & Bernadette Gutmann, CSR Specialist \\
\hline & & $\begin{array}{l}\text { Sharing of experience of Readymade Garments } \\
\text { sector in Bangladesh }\end{array}$ & $\begin{array}{l}\text { Ministry of Labour and } \\
\text { Employment, Bangladesh }\end{array}$ & Khondaker Hossain, Representative \\
\hline & & $\begin{array}{l}\text { The interdependence of health, nutrition, and } \\
\text { livelihoods: the role of academic research }\end{array}$ & University of Sydney & David Guest, Professor \\
\hline & & Government guidance around food at work & Government of Sri Lanka & $\begin{array}{l}\text { Bhanuja Wijayatilaka, } \\
\text { Consultant Community } \\
\text { Physician }\end{array}$ \\
\hline $\begin{array}{l}10: 00- \\
11: 15 \\
\text { with } \\
\text { coffee }\end{array}$ & \multicolumn{4}{|c|}{$\begin{array}{l}\text { Marketplace session with booths showcasing efforts from: } \\
\text { The Sustainable Trade Initiative (IDH) and Touton, BDA Work Ready, Consumer Goods Forum Health and Wellness Pillar, Alive \& Thrive, SUN Business } \\
\text { Network, Nutrition Connect, GAIN Virtual Reality for Workforce Nutrition, Access to Nutrition Initiative, Danone, Eat Well Global, Mars, The Institute of } \\
\text { Grocery Distribution (IGD) }\end{array}$} \\
\hline \multirow{5}{*}{$\begin{array}{l}11: 15- \\
12: 30\end{array}$} & \multirow{5}{*}{$\begin{array}{l}\text { Private Sector Actions for } \\
\text { Workforce Nutrition: Moving } \\
\text { Forward }\end{array}$} & What is the role of the private sector? & SUN Movement Secretariat & $\begin{array}{l}\text { Gerda Verburg, Coordinator } \\
\text { Moderator }\end{array}$ \\
\hline & & $\begin{array}{l}\text { The role of the Health and Wellness Pillar } \\
\text { CGF }\end{array}$ & CGF Health \& Wellness Pillar & Pauline Harper, Director \\
\hline & & SUN Business Network & $\begin{array}{l}\text { SUN Business Network } \\
\text { Global Members }\end{array}$ & $\begin{array}{l}\text { Laurène Aubert, Senior Associate for } \\
\text { Global Partnerships }\end{array}$ \\
\hline & & Sector wide support in tea & Unilever & $\begin{array}{l}\text { Katja Freiwald, Director of } \\
\text { Global Partnerships }\end{array}$ \\
\hline & & $\begin{array}{l}\text { The role of the national private-sector } \\
\text { associations for accelerating workforce nutrition }\end{array}$ & Indian Tea Association & Vivek Goenka, Chairman \\
\hline $\begin{array}{l}12: 30- \\
13: 00\end{array}$ & Closing & $\begin{array}{l}\text { Call to Action- Workplace Nutrition } \\
\text { Commitments }\end{array}$ & $\begin{array}{l}\text { The Global Alliance for } \\
\text { Improved Nutrition (GAIN) }\end{array}$ & Lawrence Haddad, Executive Director \\
\hline
\end{tabular}




\section{ANNEX 2}

Figure 1. Pathways to programme impact. Source: Stone \& Nyhus Dhillon, 2019.
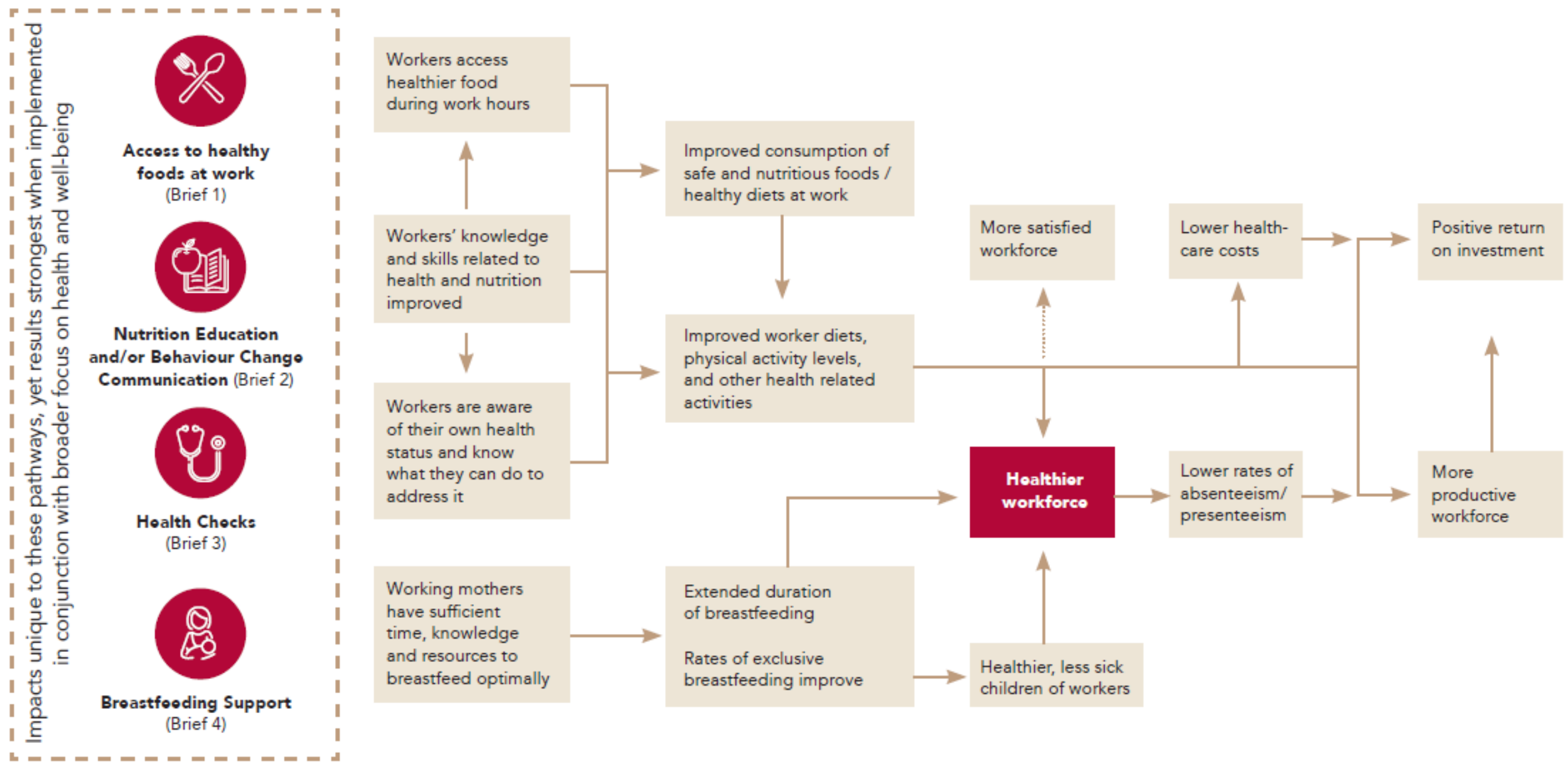


\section{ANNEX 3}

Table 1: Tools presented during a roundtable session on July 3rd, 2019.

\begin{tabular}{|c|c|c|c|}
\hline Tool presented & Organisation & Audience & Link to tool \\
\hline $\begin{array}{l}\text { Toolkit for the provision of } \\
\text { healthy food at work }\end{array}$ & Eat Well Global & $\begin{array}{l}\text { Small businesses in } \\
\text { resource-constrained } \\
\text { settings }\end{array}$ & Tool still in development \\
\hline $\begin{array}{l}\text { Service delivery models } \\
\text { for smallholder farmers in } \\
\text { supply chains }\end{array}$ & $\begin{array}{l}\text { The Sustainable } \\
\text { Trade Initiative } \\
\text { (IDH) }\end{array}$ & $\begin{array}{l}\text { Companies investing } \\
\text { in supply chain } \\
\text { programmes }\end{array}$ & $\begin{array}{l}\text { https://www.idhsustainab } \\
\text { letrade.com/approach/se } \\
\text { rvice-delivery-models/ }\end{array}$ \\
\hline $\begin{array}{l}\text { Business case modelling } \\
\text { for investing in nutrition }\end{array}$ & $\begin{array}{l}\text { NewForesight/ } \\
\text { GAIN }\end{array}$ & $\begin{array}{l}\text { Anyone interested in } \\
\text { understanding } \\
\text { business motivations } \\
\text { for investing in WFN } \\
\text { programmes }\end{array}$ & Tool still in development \\
\hline $\begin{array}{l}\text { Breastfeeding support in } \\
\text { the workplace }\end{array}$ & Alive\& Thrive & $\begin{array}{l}\text { Anyone interested in } \\
\text { setting up an } \\
\text { employee } \\
\text { breastfeeding } \\
\text { support programme }\end{array}$ & $\begin{array}{l}\text { https://nutritionconnec } \\
\text { t.org/sites/default/files/ } \\
\text { uploads/resources/201 } \\
\text { 9-04/Workplace- } \\
\text { Toolkit-11-2-2015- } \\
\text { ENG.pdf }\end{array}$ \\
\hline $\begin{array}{l}\text { Access to Nutrition Index: } \\
\text { self-assessment tool }\end{array}$ & $\begin{array}{l}\text { Access to } \\
\text { Nutrition } \\
\text { Foundation }\end{array}$ & $\begin{array}{l}\text { Multinationals } \\
\text { currently graded } \\
\text { under the index and } \\
\text { companies } \\
\text { interested in self- } \\
\text { assessments }\end{array}$ & $\begin{array}{l}\text { https://www.accesston } \\
\text { utrition.org }\end{array}$ \\
\hline $\begin{array}{l}\text { Guidelines for healthy } \\
\text { canteens in Sri Lanka }\end{array}$ & $\begin{array}{l}\text { Ministry of } \\
\text { Health, Sri Lanka }\end{array}$ & $\begin{array}{l}\text { Anyone interested in } \\
\text { seeing how } \\
\text { government policies } \\
\text { can incentivize } \\
\text { Workforce Nutrition } \\
\text { programmes }\end{array}$ & $\begin{array}{l}\underline{\text { http://203.94.76.60/de }} \\
\text { partmnt/NutritionDivisi } \\
\text { on/Nutrition\%20Guidel } \\
\underline{\text { ines/Canteen\%20Guid }} \\
\text { elines\%20English\%20B } \\
\underline{\text { ook.pdf }}\end{array}$ \\
\hline $\begin{array}{l}\text { Living income/wage and } \\
\text { costs of a healthy diet }\end{array}$ & $\begin{array}{l}\text { Global Living } \\
\text { Wage Coalition }\end{array}$ & $\begin{array}{l}\text { Anyone interested in } \\
\text { how living wages/ } \\
\text { incomes are } \\
\text { determined, } \\
\text { specifically around } \\
\text { cost of a healthy diet }\end{array}$ & $\begin{array}{l}\text { https://www.globallivin } \\
\text { gwage.org/about/anke } \\
\text { r-methodology/ }\end{array}$ \\
\hline
\end{tabular}




\section{ANNEX 4}

Table 2: Challenges discussed during working groups session and solutions reported back to the wider group.

\begin{tabular}{|c|c|}
\hline Challenge discussed & Proposed solutions \\
\hline $\begin{array}{l}\text { How much and what kind of evidence do } \\
\text { we still need on what works? }\end{array}$ & 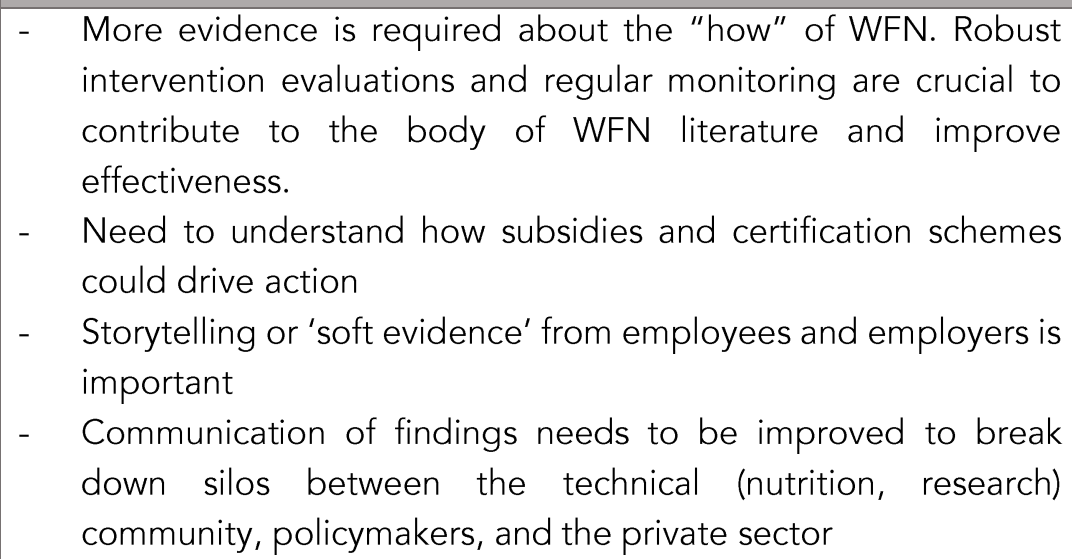 \\
\hline $\begin{array}{l}\text { How do we move from corporate offices } \\
\text { in high-income countries to non- } \\
\text { corporate, factory or farming settings in } \\
\text { developing countries with WFN } \\
\text { programmes? }\end{array}$ & $\begin{array}{l}\text { - Create internal organisational alignment between HR } \\
\text { departments managing corporate employee wellbeing and } \\
\text { supply chain sourcing departments } \\
\text { - "Connect the dots": many existing programmes could easily } \\
\text { embed nutrition in their strategy }\end{array}$ \\
\hline $\begin{array}{l}\text { How should we assess the effectiveness } \\
\text { of WFN programmes? What are the } \\
\text { business, nutrition and/or diet metrics? } \\
\text { What are the evaluation designs that } \\
\text { make sense in company settings? }\end{array}$ &  \\
\hline $\begin{array}{l}\text { How do we reach smallholders for better } \\
\text { nutrition? }\end{array}$ & 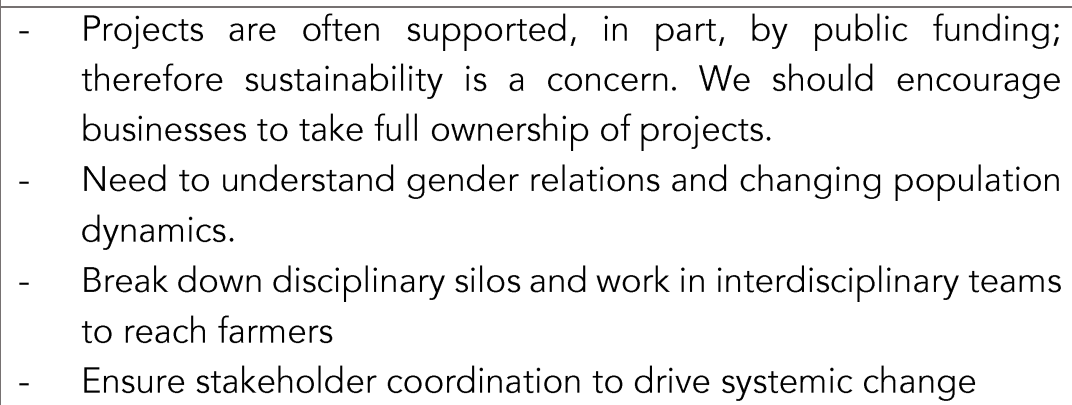 \\
\hline $\begin{array}{l}\text { How can we develop smart funding } \\
\text { mechanisms? Who needs support and } \\
\text { who does not? }\end{array}$ & $\begin{array}{l}\text { - Define how WFN fits within the global nutrition strategy of the } \\
\text { - } \quad \text { Assecade of Action on Nutrition, 2016-2025 } \\
\text { programmes to reduce costs } \\
\text { - The role of the public sector is to generate evidence, coordinate } \\
\text { and accelerate global action }\end{array}$ \\
\hline
\end{tabular}




\begin{tabular}{|c|c|}
\hline $\begin{array}{l}\text { How do we communicate our successes } \\
\text { and learn amongst ourselves? }\end{array}$ & 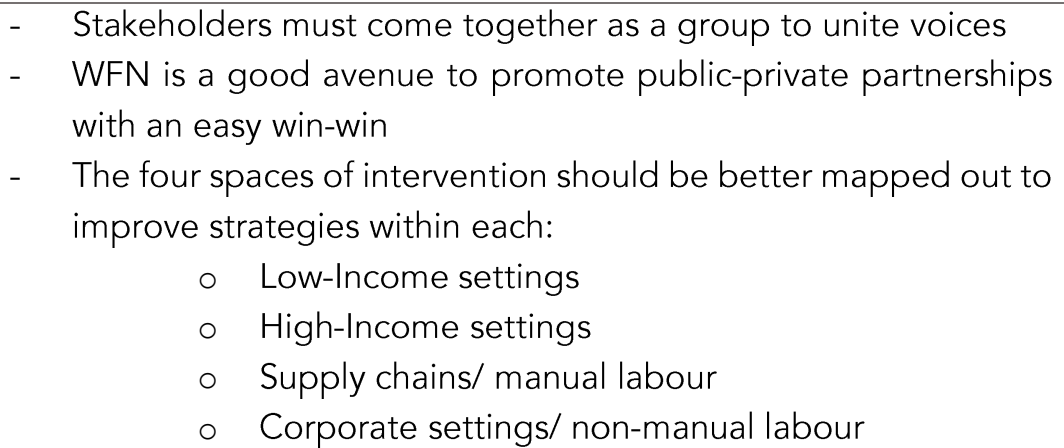 \\
\hline
\end{tabular}

